\title{
The General Competences in the Common National Curriculum Base and It's Relation with Mathematics: Conceptions of Primary School Pedagogical Supervisors
}

\author{
Karine Pertile(iba \\ Jutta Cornelia Reuwsaat Justo@a \\ ${ }^{a}$ Universidade Luterana do Brasil (ULBRA), Programa de Pós-Graduação em Ensino de Ciências e Matemática, Canoas, \\ RS, Brasil. \\ Received for publication on 18 Sep. 2019. Accepted, after revision, on 10 Oct. 2019. \\ Assigned editor: Claudia Lisete Oliveira Groenwald.
}

\begin{abstract}
This study is a part of doctorate research about the contributions of the continuous education of primary school teachers of mathematics in the Common National Curriculum Base. For such purpose, was established a discussion group made of 10 pedagogical supervisors of the early basic education city's municipal education system in the countryside of the Rio Grande do Sul/ Brazil who could, during ten meetings, discuss, analyze and reflect over the proposal of the Common National Curriculum Base for primary school. At first, the participants of the group discussed over the Common National Curriculum Base proposed competences in the fields of mathematics. The article, therefore, discusses the concepts of a discussion group composed of primary school pedagogical supervisors about the general competences for elementary school presented on Common National Curriculum Base and its relations with mathematics. The group's discussions were audio-recorded with the previous authorization of the participants. Through notes in the field researcher's diary, the participants' behaviors, inquiries, action, and reflections were watched and analyzed during the meetings. Although the group participants made consistent considerations about how to support student's skill development it was found that some notes do not conform to the focus of competences or the participants do not realize that they do not apply to the learning process, that is to say, are focused on the student. This emphasizes the need for continuous education about the Common National Curriculum Base for the working early basic education teachers.
\end{abstract}

Keywords: Mathematics Education; Continuing Education; Common National Curriculum Base; Primary School; General Competences.

Corresponding author: Karine Pertile. E-mail: karine.pertile@gmail.com. 


\title{
Base Nacional Comum Curricular para o Ensino Fundamental: as Competências Gerais e a Relação com a Matemática na Concepção de um Grupo de Discussão
}

\begin{abstract}
RESUMO
Este estudo é um recorte de uma pesquisa de doutorado acerca das contribuições da formação continuada com professores dos anos iniciais sobre a Base Nacional Comum Curricular de Matemática. Para tal, institui-se um grupo de discussão composto por 10 supervisoras pedagógicas dos anos iniciais da rede municipal de ensino de uma cidade no interior do Rio Grande do Sul/ Brasil que, durante dez encontros, discutiram, refletiram e analisaram a proposta da BNCC para os anos iniciais. Em um primeiro momento, as participantes do grupo discutiram sobre as competências gerais propostas pela BNCC, estabelecendo relações com a área de Matemática. $\mathrm{O}$ artigo, portanto, aborda as concepções de um grupo de discussão, compostos por supervisoras pedagógicas dos anos iniciais do ensino fundamental, a respeito das competências gerais para o Ensino Fundamental apresentadas na Base Nacional Comum Curricular e sua relação com a Matemática. Os encontros do grupo de discussão foram gravados em áudio, com autorização prévia das participantes. Foram observados e analisados, através de anotações em diário de campo da pesquisadora, comportamentos, questionamentos, ações e reflexões das participantes ao longo dos encontros do grupo. Embora as participantes do grupo tenham feitos considerações consistentes sobre como auxiliar no desenvolvimento das competências gerais pelos alunos, observou-se que alguns apontamentos não condizem com o foco das competências ou, ainda, que as participantes não percebem que as mesmas se referem ao processo de aprendizagem, ou seja, têm foco no aluno. Isso enfatiza a necessidade de formação continuada a respeito da Base Nacional Comum Curricular para os professores atuantes na educação básica.
\end{abstract}

Palavras-chave: Educação Matemática; Formação Continuada; Base Nacional Comum Curricular; Anos Iniciais do Ensino Fundamental; Competências Gerais.

\section{INTRODUCTION}

In December of 2017 has been approved the Common National Curriculum Base $(B N C C)^{1}$ (Brazil 2017a) for Elementary and Middle School, a normative document for the education network which refers to the elaboration of school curricula. Besides, to define the indispensable and essential set of learning to which children, young people, and adults are entitled, the document binds other policies to ensure that right, such as school curricula, teachers' training, evaluation, didactic material, and political pedagogic project (PPP).

Such changes in the Brazilian scenario in regards to early basic education makes increasingly necessary to rethink its teaching process in regards to minimum content, teacher's education, and schooling infrastructure. Especially addressing primary school teachers, which are one of the most affected areas with the BNCC (Brazil, 2017a), according to the addition of new content, continuous education events, such as discussion groups through analysis over teaching practice, urge upon the current situation.

$\overline{{ }^{1} \text { It was decided to keep its }}$ original abbreviation. 
In this perspective, it is necessary to continuously reflect and assess one's work developed in the classroom, to perceive the implications of the teaching practice in one's formation and it's importance in the students learning the process. The reflection process over teaching practice will contribute to the redirection of the pedagogical doing in search of teaching improvement.

In the search for increased motivations to direction research for the primary school, there was an effort, in some important databases, to identify the frequency of publications regarding BNCC in this teaching level. When research in Capes Digital Bank of Thesis Summaries ${ }^{2}$ was done, there were no records found about Mathematics on BNCC's bank of thesis and essays. This absence is comprehensible since BNCC is still under gradual implantation, and its complete implantation is expected for 2020. In relation to scientific articles the following researchers were made in Scielo ${ }^{3}$ Portal: "Common National Curriculum Base" where were found 35 articles about the subject, and only one of those in the contexts of Mathematics in primary school; "Common National Curriculum Base + Teachers Training", where were found 2 articles and only one of them in primary school perspective; "Common National Curriculum Base + Discussion Group", without records.

This article presents an excerpt from a doctorate's research ${ }^{4}$ undertaken by the first author and guided by the second whose focus was the continuing training of teachers who teach mathematics in primary school, based on BNCC's (Brazil, 2017a) Mathematics.

The work, directed to primary school teachers, in a small town in gaucho's countryside municipal education system, had it starts with continuing training in group discussion modality, with ten pedagogical supervisors of the primary school in the city's municipal school system, nominated by the Municipal Education Bureau. These group reflections, entitled, "The Primary School Mathematics on BNCC", were the basis for the elaboration of continuous education with teachers who teach Mathematics in the primary school.

During the discussion group meetings were studied and analyzed, the general competences present on BNCC of EF (Brazil, 2017a), between other primary school Mathematics related subjects. This article has the purpose of answering the question: What is the comprehension of a discussion group regarding the BNCC's General Competences for Primary School?

The goal of this article is to discuss the discussion's group participants' comprehension over the Primary School's General Competences proposed by BNCC and the relation to Mathematics.

\footnotetext{
${ }^{2}$ Brasil. Catálogo de Teses e Dissertações. Retrieved on September, 02, 2019 from https://catalogodeteses.capes.gov.br/ catalogo-teses/\#!/.

${ }^{3}$ Portal Scielo. Retrieved on September, 02, 2019 from https://www.scielo.org/.

${ }^{4}$ The research project was submitted to the Ethics Committee of the Lutheran University of Brazil, by the Brazil Platform, and approved under the opinion number 2.928.749.
} 
The following sections present: the benchmark that substantiates the research, with a brief overview of BNCC (Brazil, 2017a), the continuous education of teachers and the discussion groups on continuous education; the survey methodology and data analysis; results analysis; and the conclusion.

\section{THEORETICAL FRAMEWORK}

The BNCC (Brazil, 2017a) establishes knowledge, competences, and abilities are expected that all students develop during basic education. Oriented by ethical, political, and aesthetic principles outlined by Primary School's National Curricular Guidelines (NCG), the BNCC adds to the purposes that direct Brazilian education to a whole human formation and the development of a fair, democratic and inclusive society.

National reference to the development of systems and Estates, Federal District and Municipalities school's chain curriculum, BNCC (Brazil, 2017a) integrate the Basic Education national policy and will contribute for the alignment of other actions and policies on a federal, state and municipal levels, regarding teachers training, evaluation, educational content's preparation and the criteria for the adequate infrastructure offer for education's full development. In this regard, it is expected that the document helps to overcome the fragmentation of educational policies, provides the strengthening of the collaboration regimen between the government's three spheres, and be the vessel of educational quality.

The CNE/CP n² Resolution, from December of 2017 (Brazil, 2017b), establishes two years for the public and private schools to be aligned with the Base's devices. This alignment's work should have preferably happened until the beginning of 2019. Schools, teachers, educational systems, textbooks, and evaluation on a wide-scale have been impacted by BNCC of Middle and Primary Schools.

In terms of teachers preparedness concerning education, according to BNCC (Brazil, 2017a), it is the Union's responsibility the standardization and orientation of the basic education courses and the promotion of actions for the continuing training of teachers. The National action has become extremely relevant since it addresses the sphere that answers for the regulation of higher education, the level in which a large part of these professionals is prepared. In the face of the evidence on the relevance of teachers and other staff members for the success of students, this is a fundamental action for the effective implementation of BNCC.

Besides the preparation of teachers regarding $\mathrm{BNCC}$, it is still competency of the Union the promotion and coordination of actions and policies in federal, state, and municipalities scope, regarding evaluation, the development of teaching material, and the criteria for the offer of adequate infrastructure for education's full development. 
Apart from guaranteeing school access and permanency, systems, networks, and schools must ensure a common level of learning to all students, a task for which the BNCC (Brazil, 2017a) is cited as a fundamental tool. Over the Basic Education, the essential apprenticeships defined by BNCC (Brazil, 2017a) should compete to assure students the development of ten general competences, which substantiate, in the pedagogical scope, the rights to learning and developing.

The BNCC defines competence as "the mobilization of knowledge (concepts and proceedings), abilities (practical, cognitive, and socioemotional), attitudes and values to solve complex demands of day to day life, the full exercise of citizenship and the working world"(Brazil, 2017a, p.8).

That is to say, BNCC (Brazil, 2017a) emphasizes the need for students being able to employ the knowledge acquired in school to daily life, always respecting ethical principles, human rights, social justice, and environmental sustainability. The document also points out that schools promote not only intellectual development but also the social, physical, emotional and cultural ones, comprehended as fundamental dimensions for a full education perspective. This differs from abilities, which focus more on cognitive development.

To Shulman (2015), if the teacher's knowledge was organized in a manual, it should include the following base categories: knowledge of the content, pedagogical knowledge of the content, curriculum knowledge, general pedagogical curriculum; knowledge on students and their characteristics; knowledge of educational contexts; and knowledge of the goals, purposes and values of education.

Therefore, a study about BNCC (Brazil, 2017a) is justified by the fact that the knowledge about this document allows the teacher a way to acknowledge the four categories suggested by Shulman: the content, the pedagogical content, the curriculum and the purposes of education. To the teachers already acting is necessary to rethink the continuing education, in order to track changes in educational policies and, therefore, the teaching process.

The concept of continuing training comes from the "condition of the incompleteness of human beings and the awareness of this incompleteness" (Freire, 1996, p.40). Therefore, the continuing education is based on a professional development successive process of the trainer teacher before an interconnection between their early formation, corresponding to their learning experience on formative and continuing formation, which configures as a process during the professional practice.

To Freire (1996, p.39), “on teachers' continuing education, the fundamental moment is the critical reflection over the experience." Freire (1996) appointed that the continuing formation's main goal is to encourage the appropriation of its knowledge towards an autonomy that takes it effectively to a critical reflexive experience. 
Is thinking critically about today or yesterday's experience that it is possible to improve the next experience. The theoretical discourse itself, necessary to a critical reflection, is concrete in such a way that it is almost confused with the experience. It's epistemological detachment from experience, while the subject of analysis, should bring it as close as possible. (Freire, 1996, p.39)

For Imbernón, the continuing education

[...] will have as a base a reflection of the subjects over their teaching practice in a way that allows examining their implicit theories, functioning schemes, attitudes, etc., performing a constant self-evaluation process that guides their work. The orientation for this reflective process requires a critical proposal of educative intervention, a practical analysis from the ideological assumptions, and an underlying behavioral point of view. (Imbernón, 2010, pp.48-49)

This means that the formative process should promote situations that enable knowledge exchange between teachers, through articulate projects of joint reflection. Imbernón (2010) pointed that school needs to be seen and encouraged as a locus of teachers continuing formation, justifying that even though the teaching profession has a subjective part, it also implies a collaborative part.

From the reflective practice perspective, in which the teacher should, besides searching their reflection, instigate their student to reflection, many research fronts developed different analyses of this process from which arise the considered relevant to the thesis.

Alarcão (2011) proposes strategies to be developed for professional teaching reflection. Among the strategies outlined by the author to promote the essential aspects of teachers' reflection are the discussion groups. In these, the exchange of experiences complements the discussions and facilitates the refection through the collaboration of individuals.

For Pivetta and Isaia (2014), the discussion groups come from the necessity of formation, stem from the teachers' doubts and awareness over the importance of reflection on their experience. The debates can involve personal dimensions (objective or subjective), limits, and difficulties encountered in the classroom. By sharing their experiences with colleagues, teaching professionals have the possibility of work through their mental representations, aiming to build from a critical and reflexive perspective, as analyze the events and seek to understand the situations and what they may represent in a professional and personal level.

Such reflections generate, on the individual and in the collectivity, the ability of the teachers to assume a new stand in their actions, providing learning. The confrontation 
and exchange of ideas enabled by the discussion group lead to teaching performance, beginning with redefinition and encouraging a profession's change and transformation.

The possibility of a critical reflection is one of the aspects to be incorporated in the continuing and early teachers' formation, for them to be significant and result in reflective professionals in the learning process.

Nóvoa (1997, p.26) states that "the formation of collective network constitute, also, a decisive factor of professional socialization and affirmation of teachers own values." For the author, dialogue between teachers is fundamental to consolidate emerging knowledge of the work experience. "The exchanging of experiences and sharing of knowledge consolidate mutual spaces of formation, in which each teacher is called to play, simultaneously the roles of trainer and trainee" (Nóvoa, 1997, p.26). From this perspective, the author points out that collective formation practices contribute to professional emancipation and the production of docents' knowledge and values.

In this perspective, the discussion groups are presented as a relevant tool in teachers' continuing formation.

\section{METHODOLOGY}

The part of the research here presented focus on a discussion group conception concerning the general competences for the Primary School presented in BNCC and its relation to Mathematics.

The participants of the investigation that composed the discussion group were ten supervisors of the Primary School in the city's municipal education system, and a representative from the Municipal Bureau of a city in the countryside of Rio Grande do Sul. The Municipal Bureau invited the supervisors, and out of a total of 21 primary schools, ten schools expressed interest in participating through their supervisors. The discussion group gathered during ten meetings, with an average duration of three hours each, between September and November 2018.

Among the ten supervisors, one has a degree in languages, one has a degree in Physical and Biologic Science, and eight of them have a degree in Pedagogy, one of which also has a degree in Psychology and another also has a degree in Physical and Biologic Science. Nine of the supervisors have more than ten years of working in the primary school.

The group meetings were audio-recorded, with previous authorization of the participants. Behaviors, inquiries, actions, and reflections of the participants during the group meetings were watched and analyzed, also through notes in the researcher's diary. The supervisors' names were altered to preserve their identity. To nominate them it was chosen the following code: "Sup", followed by one of the alphabet letters, from A to J. The order of choice was decided according to their manifestations during the group meetings. That is to say, the first to speak up was called SupA, the second of SupB and so on. The 
representative from the Municipal Bureau was called RES. The group was coordinated by this article's first author, denominated coordinator researcher (CR).

The supervisors' narratives in the discussion group meetings established the investigation corpus, which was discussed in this article through an interpretative and descriptive analysis.

\section{DESCRIPTION AND INTERPRETATION OF THE MEETINGS}

The General Competences of BNCC (Brazil, 2017a) define the kind of citizen we want to shape. The discussion began by questioning the supervisors about what is competence. SubB answered: ${ }^{5}$ A set of abilities. SupD, in turn, answered it Is doing it well, know how to apply an ability. SupH, in a clear and succinctly way, pointed the competence as being the junction between ability, plus knowledge, plus attitude.

Then the CR presented the definition of competence presented by BNCC. The ten competences were presented and discussed, one by one, with the supervisors, the CR emphasized there doesn't exist a hierarchy between competences, but a "articulation of knowledge building, in development of abilities and in the formation of values, in LBD terms" (Brazil, 2017a, p.9).

To make comprehensible to the group participants, the CR presented her interpretation of the first two competences, then requesting that the group think over the others. The aim was that the supervisors exchanged experiences and shared knowledge, from the perspective of what Nóvoa (1997, p.26) points to as "trainer and trainee" in spaces of mutual formation.

Competence 1 (Knowledge): The knowledge in the areas are mobilized not just to understand and explain reality, but also to make choices based on this understanding and act in a particular direction. (CR)

Competence 2: (Scientific, Critical, and Analytical Thought): In this competence, the focus is on ability mobilization and in cognitive processes that develop perception, attention, memory, and reasoning; problem-solving and, investigation procedures. (CR)

Concerning competence 3, whose focus is cultural repertory, SupC emphasized that the school has to provide spaces where the students can express themselves culturally and artistically. The other supervisors endorsed this idea.

However, the CR asked that they did not think just about school, in a supervising way, but also a teacher, to contribute to their work in the classroom. It was also requested, if possible, to think about how to achieve the appropriate skills in Mathematics classes. The impression given is that Mathematics teachers are "that" and don't open up for creative space. [...] And that is why I think it's so difficult to create within a field with such restrict knowledge. (SupC). The supervisor's speech points to a mystification of Mathematics as if it is a detached knowledge from the other areas.

${ }_{5}^{5}$ The group participant's statements when transcribed are shown in Italics. 
The supervisors pointed works with projects, interconnecting the different areas of knowledge. SupD, for example, reported her school's experience, where different classes of the primary school worked with different historical periods, focusing various artistic and cultural manifestations - pointed, however the difficulty in insert Mathematics in the historical context.

Once again, it seems like Mathematic seems as a knowledge detached from human needs without artistic or cultural characteristics. The supervisor pointed yet, that one of the teachers concerned, during the project, suggested that we calculate everything we will work with. (SupD). Such say goes against the first competence specific to Mathematics presented by BNCC:

Recognizing that Mathematic is a human science, born from different cultures' needs and worries, in different historical moments, and is a live science, which contributed to solve scientific and technological problems and to support findings and constructions, including its impacts on the working world. (Brazil, 2017a, p.265)

The SupG referred that the teacher can raise the action, can present different artistic manifestations, and from then on, request that the students identify, for example, geometrical forms, to work in Mathematic. The supervisors mentioned the logic blocks as a resource for such a purpose. Then SupI pointed out that play-acting can be used to promote comprehension over problem-solving situations since the students have difficulties comprehending mathematical challenges. Also mentioned the Museum of Science and Technology that belongs to a private university in the State Capital, in which the students perceive the contents more practically and interactively.

With the participation of the supervisors, it was established then, that the competence presented in the cultural repertory established that the students acknowledge, comprehend, and recognize the importance of the most diverse artistic and cultural manifestations, by participating, capable of acting and expressing themselves through the arts.

Initially, SupC pointed out the difficulty in developing competence in mathematics class. However, with the experiences exchanged between the supervisors, they were able to comprehend that it is not something truly difficult. This knowledge exchange is reminded by Imbernón (2010) as part of the formative process, through joined reflection.

In the perspective of Competence 4, which provides the use of different means of communication, SupC mentioned works done in fairs, in which the students have to present, explain, argue and justify their projects.

SupD comprehended that the competence concerned the languages to be used by the teachers. I think that using different languages is what this competence is about. Everything we can use will affect the ways the student comprehends, how the knowledge reaches him... Because sometimes the teacher explains in a way and the student sometimes 
is more visual or more auditory...there are people who need to write to see, to record, to learn... others need to do to be able to learn. What I understand about this is that we need to use every tool, so we can build knowledge, so we can build understanding...to reach all we have to use every form of language (SupD).

The CR intervenes emphasizing the example refers to moments of teaching, but the point of the languages concerns a competence to be developed on the student, through study objects, just as all the general BNCC competences. But, yet, the interpretation of the supervisors doesn't seem to change, as seen by the SupA next saying, which visibly concerns teachings methodology.

For me, a keyword of this competence would be 'reinterpretation'. It can be used as a book reading with the students to teach elements. For example, in mathematics, multiplication, and division. And if from other areas as well... the visual question... I can take literature and work with images reading (SupA).

The SupB talked about the use of Brazilian Sign Language at school, emphasizing that it is an important language, according to a large number of students with hearing impaired the schools are receiving. Then, Sup D contributed by explaining that in kindergarten, in the school where she works, the students have been learning the Brazilian Sign Language. SupI explained that the school where she works there was also an assignment about Brazilian Sign Language.

The CR resumed the discussion by questioning the group participants about how is possible, as teachers who taught mathematics, to assist the student in developing the competence of using different languages. That is to say, how can we make the students transform mathematics language in a native language and vice-versa.

Thinking again on this situation of the student knowing how to express himself, I think that for him to know how to express he needs to comprehend. In a Mathematical situation, I was doing homework with my little one, who is in the First Year. And the lesson used golden material, and he said to me: 'Mother, when it reaches ten it needs to be exchanger to a bar'; 'But why does it have to be exchanged to a bar?'; 'Because the bar has 10.'; 'Ten what, son?', and this went until he comprehended that in a bar there are ten small cubes. And then he was able to express himself. Of course, for a teacher in the classroom with all students, it's not possible this dialogue with each student, but the students must be encouraged to have arguments to able to better express themselves. If they don't feel safe in arguing they won't be able to express themselves too (RES).

SupI showed concern over the teacher preparation in the teaching process, to contribute to the developing of this competence by the student. The SupA pointed out the necessity of the correct use of the mathematic language by the student. The SupC points to the necessity of the student knowing the correct language to express himself.

The SupI, in perspective of what is suggested by BNCC (Brazil, 2017a), pointed that the work regarding the development of the mathematical language by the student should be done gradually, but should not be abandoned. The CR mentioned the 
importance of the teachers' knowledge and domination of the mathematical language, aiming to assist in a significant way the development of this competence by the student.

The care with the use of the correct mathematical language is mentioned many times in the teachers' orientations, presents in the commentary section online of BNCC, such as the one quoted below:

Stands out the need to take care that the mathematic language is used by the teacher, since expressions like 'more' 'less' 'equal' 'different' are also expected from the students and only will happen if there is a concern for its occurrence. [...] the encouragement of varied records are part of the process of mathematic language's built support, amplify the intellect and the argumentative capacity of students. This applies to general problem-solving situations. [...] it's worth mentioning to be careful with the representation forms and the introduction of the mathematical language regarding divisions. (Brazil, [2018], s.p.)

This made me remember. We keep trying to use these other forms... There was this teacher teaching addition, subtraction. 'you have five candies, and you eat two, how many candies do you have?' and the student said, 'with five!'. [the teacher] 'Look! You have five, you eat two...' [Supervisor showing the fingers to represent the situation]. And the student kept saying 'Five'(SupD).

The supervisors' speech points to the necessity that the teachers built with care and attention the problem-solving situations, especially with the implementation of BNCC, which indicates a problem solving as an object and as a learning methodology, as well as investigation, projects developing and mathematical modeling.

The mathematical processes of problem solving, investigation, projects developing and modeling can be mentioned as privileged ways of mathematical activity, which is why they are, at the same time, object and strategy for learning during the whole Elementary School. (Brazil, 2017a, p.264, author's emphasis)

The supervisors were able, at this moment, to reflect and rethink the teaching practice, on Freire's (1996) perspective of critically reflect over the current practice to improve the future practice.

The $\mathrm{CR}$ concluded the reflection over the Competence stating that not all the students will know how to always use the same language. And BNCC is clear on that when points that, in specific situations, the student can make representations in the best form he sees fit. For example, on BNCC's online orientations, we have, in what concerns the ability to built addition basic facts, for Elementary school first year: 
The building of basic facts arises from the procedure development for problemsolving, knowing different manners of representation, moreover with the presentation of the addition, subtraction and equality signs, without demanding that this writing be the only manner of addition solving problems. (Brazil, [2018], s.p., our emphasis)

When discussing Competence 5, that addresses comprehension, creation, and use of Information and Communication Digital Technologies (ICDT), SupB mentioned the fact that, even though students have access to a large amount of information, through Smartphone's, only a few know how where to do researches.

Sup D points that is exactly what this competence means. It is what says there: 'in a critical, significant, reflective, and ethical way'. It is where the teacher comes in: guiding how he is going to use this. But he is also going to need the other competences to do to it. Because what we need to do now, to integrate technology with them: orientate, mediate this mean of communication [smartphone] with knowledge, that they interpret that a piece of particular news, a particular website can be fake...they have to read the whole. Because they [the students] are directing technology for their interests...(SupD).

The supervisors mentioned the use of social networks and the need to work ethics in what refers to them. SupC mentioned that students use the social network to commit bullying, which ends up involving the students' families, who use the school as a resource to try to solve the conflict.

The CR then remembered that students now in elementary school are called 'digital natives' (Prensky, 2001). However, we, teachers, are the 'digital immigrants'. We are adapting to the digital environment but always connected to the past. That is why our language is not the same as the students' (CR).

For the $\mathrm{CR}$, as already mentioned by $\mathrm{SupC}$, the teacher has to supervise the work made by the students, when they have internet access and, even more, mediate the research process, by presenting trustworthy websites.

SupI pointed out that the ability to use the ICTD still has to be developed by the teachers. We are still on that journey. (SupD). The supervisor's speech points to an important reflection over teaching practice, admitting that a teacher is in constant formation, as suggested by Freire (1996) and Alarcão (2011).

As pointed by Batista and Barcelos (2013, p.2), the smartphone "receives a few criticisms by teachers concerning problems they bring, such as distraction, deviate the students' focus from the subjects addressed in the classroom". The author's affirmation comes in line with the supervisor's speech, who show more concern over its use than see the smartphone as a facilitating tool on the teaching and learning process. To Carvalho (2018), using apps with a didactic purpose demands on the teacher's part a well-drafted work plan so there can be apprenticeship. 
Regarding Competence 6, which is focused on the working world and in the students' life project, SupB mentioned that cultural experiences are widely worked, according to the city's and state's history. SupG talked about Afro-Brazilian and Indian cultures. The CR emphasized that, according to the DCN for Basic Education (Brazil, 2013), teaching about those cultures is mandatory.

About the life project, SupA presented an interesting reflection. I think it is very important this ability that speaks about life project. If we start from the basics, valuing the dreams, working with them on their self-esteem, they will reach high school, maybe, knowing how to make choices, being able to choose an adequate manner. Because even today, in [high] school, we perceive that some still follow what is predetermined by their parents (SupA).

I think one of the school chores is to make the young think, dream, have goals, have objectives (SupC). The supervisor showed concern with the fact that a lot of young people don't demonstrate an interest in plans.

SupB pointed out the importance of a project SMED develops within schools, in which students from kindergarten until the third year of Elementary School visit fortnightly the city's ecologic fair. The students end up learning to do price research, calculate the change, to save up. This project is very important (SupB).

SupE, who works in a school where various students find themselves in a situation of social vulnerability, told that, after the fair, the students share some fruits to make a fruit salad to be shared between all of them. They already learn how to socialize, to share (SupE).

The CR then requested the group to reflect on how the students could put their regional knowledge when exercising their citizenship, which was satisfactorily answered by SupI.

We have this idea that cultural means art, dance, theater, anyway... But there is also the culture of the region, of the countryside worker, the city worker or who doesn't work. [...].it seems to me it's also about gender, by women appreciation, and all of this somehow develops the issue of citizenship, of critical awareness, choices responsibility, opinions, guesses [...] The working world demands a world of wisdom, not only the ones connected do work (SupI).

In the view of Competence 7, which concerns the development of a fact-based argumentation, the SupI mentioned the fake news. The CR reminded that when dealing with digital natives, which the first source of information usually comes from the internet, it is important for the teachers to teach about how and where to do researches based on trustworthy information, something already been mentioned in the previous meeting.

When dealing with social networks, SupC pointed out the importance of checking the received information before sharing them, the topic addressed by the teachers in their school. The supervisor also told that a large part of the posts at the school's profile 
page on Facebook is created by the students, so they can understand the responsibility of sharing correct information on social media networks.

Sup A coherently pointed out the influence of the media over people's opinion formation. SupI pointed to the difficulties students find to argumentation when writing an essay, for example.

About the 'self-care', Sup H reminded that social media networks are allowed only for people over 13, which is not the case of the early year's students. For them to have Facebook access, for example, the students increase their age, and the parents are conniving with this attitude.

To help to develop this competency, in a sense that the students can develop their argumentative capacity, the $\mathrm{CR}$ emphasized that texts based on real data should be used in the classroom.

SupF pointed out that in her school, in what concerns socio-environmental responsibility, a project was developed embracing students from kindergarten until the ninth year of Elementary School. Kindergarten A, for example, is studying the substitution of industrialized juice for a natural one. Kindergarten B the substitution of white sugar for brown sugar. [...] And we began all of this with a problem. There is a problem each year. Each year had a problem to solve. The research was made. Each year went home with a question. They collected data with family, neighbors, anyway...Then each year built chats with the collected data. Each chart according to the grade's capacity, of course [...] Besides the charts, they also worked with mental maps, so they could organize themselves for the moment when they had to explain to the people who visit the works (SupF).

The supervisor's speech presents an example of an activity where the students come across real data, and through them, are capable of building arguments to defend their point of view. Besides based on the themes chosen by the students, it can also be observed that the students develop their capacity to care for themselves and others.

SupF referred that the project was an even bigger problem: the issue of the waste of food and material resources. The students of the late years are working with food waste on break time. They write down how many students have the meals provided by the school, how many kilos of food went to waste, how much is the cost to the school, what will be made of the rest of it can be put in the compost heap or if it can be reused... The kitchen oil, to make soap ...(SupF). Through this generating problem, new problems arose and the students searched for solutions based on real data. Besides according to the supervisor, the students have shown interest in another topic, such as the physical fitness of the street cleaners who work with the garbage truck.

Competence 8 is related to the developing of self-knowledge and self-care by the students. In this sense, SupB pointed out the necessity of teachers caring for their emotional health. Then SupI, who has a degree in psychology, mentioned that teachers, just as mental health professionals, should also receive medical attendance, to know how to deal with certain situations. 
With the supervisors' reflections, it can be noticed their worries towards teachers' overexertion. However, they perceived the competence as if related to themselves when, however, it is related to the students. The CR mentioned that the competence was about the students. They should develop the capacity to take care of their physical and mental health. It's a school role to assist in this development.

Initially, the participants didn't give significant answers related to the competence, answering in a way distant from the expected. SupB spoke about students who have been diagnosed with Attention Deficit Hyperactivity Disorder (ADHD), what according to her, have been happing more frequently annually. SupG spoke about drug-addicted students. SupE referred about severe problems the students face at home, quoting the case of a student who went to school to ask for help in regards to an alcoholic father. All the speeches are especially delicate, and this research has no intention - even less possibility- to deal with such problems.

SupH then pointed out something very important: I think this emotional issue makes all the difference in the learning process. Nobody is capable of learning in these conditions. [When talking about SupE's account]. The supervisor is also a Resources Classroom teacher and mentions how difficult it is to work the psychological side of the student who attends the resources class. By being students who have learning difficulties, they are afraid to commit mistakes when are not in a class, and, therefore, don't even try to answer the questions proposed by the teacher. In that way, the supervisor encourages every accomplishment in the resources classroom, intending to increase their self-esteem.

SupH's speech points to an example of how the school can assist the students in their self-comprehension, recognizing their emotions and learning how to deal with them. But is also possible to realize that her encouragement, as a teacher, has a big impact on the learning process.

Vygotsky $(1998,2000,2001,200)$ marks the individual's development as a process built on and for the interactions one establishes in the historical and cultural context in which it is inserted. The building of knowledge begins in an intense process of social interaction, and therefore begins by the child's insertion in the culture, developing, since social interactions are responsible for acquiring the knowledge built along with history. "All the functions of a child's development appear twice: first on a social level, then on an individual level; first between people (inter psychological) and then in the child's interior (intra psychological)" (Vygotsky, 1998, p.75).

To the teacher is required not only that the student learns the subjects, but is also capable to feel the subjects relating them to emotions. In that way, Vygotsky (2001) state that the teacher should concern himself with relating the new knowledge with the emotion, otherwise the knowing becomes dead.

Concerning competence 9, whose focus is on empathy and cooperation, SupI referred to the project previously presented by SupF, stating that it can help the student to develop this competence. 
SupC mentioned a project realized at her school, named "Good Network: White Butterflies", created to develop empathy and dialogue, to solve conflicts. The supervisor explained that late years students realize activities with younger students, such as playful activities. This also happens at lunch. Since the school is an all-day school, the students have lunch at school.

Some supervisors quoted the interaction with refugees who come to live in the city. The CR complemented by saying the teacher should encourage the reception of these students, using their knowledge, appreciate their culture, so they can be an example for their students. The CR also mentioned the Indian issue. The schools should go beyond celebrating "Indian's Day", provide subsidies for the students to know Indian history and culture. SupI pointed to the importance of valuing the regional culture, in this case, Italian culture, through immigration history, and the dialect still spoken in the region.

We realize that where is a child with a disability [...], the children understand that, and they cooperate. Someone in a wheelchair, they cooperate, help [...] A child is like that, helping, cooperate... (SupB). SupB's speech presents another perspective of school inclusion: the possibility of conviviality with students with special needs, and the learning of conviviality, cooperation, reception. The RES pointed out that, in her opinion, an included student with special needs humanizes the relationships between students.

SupJ stated that although school inclusion presents several positive points, it is still a cause of concern. There inclusions cases that cannot be handled by the school (SupJ). For SupH, the worry is about these students' apprenticeship. The inclusion theme still is polemic and demands a lot of studies. However, school inclusion as perceived by the group reflections, benefits everyone, especially in regards to living in society, respecting the differences.

The CR then questioned if the schools address gender-related issues. We don't address. At school, we have the girls' bathroom, the boys' bathroom, we do a boys line and a girls line [...] we don't encourage (SupB). The supervisor showed discomfort while talking about the theme.

At school, there is also the boys'line and the girls'line. If any student presents any problem with it, then we are going to look for a solution as soon as possible (SupC).

By the supervisors' speech, we can see that they believe addressing gender issues means the student's sexual orientation. While, in truth, the CR intention was that the students would learn how to live with and respect everybody, the true meaning of the analyzed competence. This can be explained by SupH's speech.

Last year we had a student in the third year who had two mothers. One day, one of them came to school and requested to talk to the teacher. And the classmates kept saying: 'No, that is the father'. They argued that this was the father because she was the one who presented herself in a more male-orientated manner ( $\mathrm{SupH})$. According to the supervisor, the students already have contact with these situations in their day to day life. 
The CR closed the discussion by explaining that although the schools think they don't need to address the issue because the students don't demonstrate sexuality-related problems, the gender issues go beyond that. But what needs to be worked on especially with and within the student is about diversity and respect to all. About gender identity: Taboo stops being a Taboo when the subject is clarified (CR).

The supervisors didn't express themselves concerning human rights, racial and religious issues, for example. The fact that raises an important reflection: many of the teachers who act in primary school are not prepared or know to assist in developing the general competences proposed by BNCC (Brazil, 2017a). This leads to the following question: How does a licentiate degree has to be structured so the Primary School teachers are prepared to teach accordingly to $\mathrm{BNCC}$ ?

Competence 10 addresses the developing of responsibility and citizenship by the students. An emerging topic was the lack of the students' responsibility with external evaluation. As put by SupD, late and final years students of Elementary School, in her school, didn't answer properly the last applied Prova Brasil. They simply marked all the questions, straight on the grid, the same alternative to all the questions.

The protagonism was a theme in some speeches, from the perspective that the student, when needing to face something, learns how to act collectively and independently, developing responsibility. The ethical, democratic, inclusive, sustainable, and supporting principles have to be managed daily, in all its contents, whether by readings and discussion of writings or by researches made by students.

We researched school about 'How much does it cost to have a child?'. Then the groups [classes] were divided, and each group should research a theme. For example, education, health, food supply...there were some very nice discussions. The protagonism made them own that. [...] In the end, all of them concluded that they could not have siblings. And all of them had...(SupD).

At school, the second-year students have a project, which they develop along with the kindergarten students, inside the theme, where they go to kindergarten to see how is to care for a baby. And they go there to experience childcare (SupE).

SupH observed that when achieving the other competences, this end up included. I don't know if it is because the last one being discussed, but for me, it seems like, when working to develop the other competences, the collaborative sense and up being contemplated (SupH).

The CR closed the discussion about General Competences emphasizing that they are built through abilities developed in each knowledge area.

Although all the discussion group participants were present at the meetings in which the General Competences were discussed, not all of them spoke, or even, some of them just made a few notes. To Pivetta and Isaia (2014), the silence assumes different meanings, as group feelings of reflection, restlessness, tranquility, insecurity, doubt, fear, or shame. These feelings can also represent resistance presented by the individual in a 
group process, a mix of themselves and others who know each other, deny or recognize as the group progresses. The silence can also represent the escape from themselves or the others since the group becomes revealing of the human condition that gradually starts to emerge.

\section{CONCLUDING REMARKS}

This article had the intention of reflecting over the conceptions of a group discussion, composed by pedagogical supervisors of the primary school, about the general competences proposed by the BNCC of Elementary School and its relation with Mathematics. By the conducted analysis, it is possible to verify that the supervisors, most of them, still didn't comprehend the presented competences, especially in what concerns how to approach and develop these competences with the teachers and their students in a school environment.

However, through the joint reflections realized in the discussion group, the supervisors were able to trade, and self assess their work, as a part of a formative process suggested by Imbernón (2010). During the meetings where the General Competences proposed by BNCC (Brazil, 2017a), were discussed, there were moments of critical reflection over the pedagogical practice e knowledge exchange, just as suggested by Imbernón (2010), Nóvoa (1997), Alarcão (2011) e Freire (1997), was given the opportunity to the group participants to a teaching continuing formation, beginning by the redefinition and encouraging the change and personal transformation.

It is understood that the examples bought by the supervisors about the projects and activities carried at the schools, as well as the discussions resulting from the Mathematics teaching with general competences, drifted towards a better comprehension of how BNCC's general competences, could be articulated with the competences and abilities regarding Mathematics. It is recognized the relevance of the creation of times and spaces of discussion between and with teachers so that understandings and joint actions in schools promote the students learning.

\section{ACKNOWLEDGMENTS}

We thank the support of Rio Grande do Sul' Federal Institute of Education, Science, and Technology, for their support in the realization of this paper.

\section{AUTHOR'S CONTRIBUTIONS STATEMENT}

K.P developed the theoretical frame, organized and applied formation, raised and registered data. J.C.R.J supervised the project, guided the data collection, and revised the 
theoretical frame. Both authors analyzed the data, discussed the results, and contribute to the final version of the manuscript.

\section{DATA AVAILABILITY STATEMENT}

The data supporting this study will be available by the corresponding author, K.P., upon reasonable request.

\section{REFERENCES}

Alarcão, I. (2011). Professores Reflexivos em uma Escola Reflexiva. São Paulo: Cortez. Batista, S. C. F. \& Barcelos, G. T. (2013). Análise do uso do Celular no Contexto Educacional. Renote.11(1), 1-10.https://seer.ufrgs.br/renote/article/view/41696/26448. Brasil. ([2018]). BNCC em Planilha. Retrieved on August, 02, 2018 from http://download. basenacionalcomum.mec.gov.br/.

Brasil. (1996). LDB - Lei $n^{\circ}$ 9394/96, de 20 de dezembro de 1996. Estabelece as diretrizes e bases da Educação Nacional. Brasília, DF: MEC.

Brasil. (1998). Parâmetros curriculares nacionais: matemática. Secretaria de Educação Fundamental. Brasília: MEC/SEF.

Brasil. (2013). Diretrizes Curriculares Nacionais Gerais da Educação Básica. Brasília, DF: MEC, SEB, DICEI.

Brasil. (2017a). Base Nacional Comum Curricular. Brasília: MEC/CNE.

Brasil. (2017b). Resolução CNE/CP 2. Institui e orienta a implantação da BNCC. Brasília: $\mathrm{MEC} / \mathrm{CNE}$.

Carvalho, M. (2018) Tecnologia Touchscreen na Formação do Pedagogo que irá Ensinar Matemática. In: Flôr, C. C. C. \& Carneiro, R. F. Formação de Professores dos Primeiros Anos de Escolarização: Temas em Ciências e Matemática. (pp.185-195). Curitiba: Appris Editora.

Freire, P. (1996). Pedagogia da autonomia: saberes necessários à prática educativa. São Paulo: Paz e Terra.

Imbernón, F. (2010). Formação docente e profissional: formar-se para a mudança e a incerteza. São Paulo: Cortez.

Nóvoa, A. (1997). Formação de professores e profissão docente. In: Nóvoa, A. (Org.). Os professores e sua formação. (pp.23-34). Lisboa: Dom Quixote.

Pivetta, H. M., \& Isaia, S. M. (1). Grupo reflexivo de professores da educação superior: Estudo sobre seus movimentos construtivos. Revista Portuguesa de Educação, 27(1), 111-132. https://doi.org/10.21814/rpe.4300.

Prenksy, M. (2001). Digital natives, digital immigrants. OntheHorizon, 9(5), 1-6. https:// www.emerald.com/insight/content/doi/10.1108/10748120110424816/full/html.

Shulman, L. (2015). Conhecimento e ensino: fundamentos para a nova reforma. Cadernos Cenpec|Nova série, 4(2). http://dx.doi.org/10.18676/cadernoscenpec.v4i2.293. 
Vygotsky, L. S. (1998). A formação social da mente. 6.ed. São Paulo: Martins Fontes. Vygotsky, L. S. (2000). A Construção do Pensamento e da Linguagem. São Paulo: Martins Fontes.

Vygotsky, L. S. (2001). Psicologia pedagógica. São Paulo: Martins Fontes.

Vygotsky, L. S. (2004). Pensamento e linguagem. 2.ed. São Paulo: Martins Fontes. 